\title{
PISA-LIKE PROBLEMS USING ISLAMIC ETHNOMATHEMATICS APPROACH
}

Muhammad Win Afgani*, Retni Paradesa

Universitas Islam Negeri Raden Fatah Palembang, Indonesia

\begin{tabular}{l}
\hline \hline Article Info \\
\hline Article history: \\
Received Nov 19, 2019 \\
Revised Apr 8, 2021 \\
Accepted Apr 11, 2021 \\
\hline
\end{tabular}

\section{Keywords:}

Islamic Ethnomathematics, Mathematics Problems, PISA

\begin{abstract}
The study aimed to produce PISA-like mathematics problems with the Islamic ethnomathematics approach that were valid and practical. A development study with formative evaluation was used as the method in this study with 32 9th-grade students as the subjects at one of the junior high schools in Palembang, South Sumatra province, Indonesia. There are five phases: selfevaluation, expert review, one-to-one, small group, and field test. Interviews, questionnaires, and tests were used in this study as the instruments to collect the data. The results showed that three experts from the expert review phase assess that $77.78 \%$ agree that six PISA-like mathematics problems meet the validity criteria. For the practicality criteria, three students from the one-toone step set about $77,78 \%$ agree, three students from the small group phase assessed about $61,11 \%$ strongly agree, and 26 students from the field test phase considered $61,33 \%$ agree. This result is supported by the average test result that was classified as a low category. This showed that the results obtained are not optimal because students still did not understand the problems and had difficulty solving them.
\end{abstract}

Copyright $(2021$ IKIP Siliwangi. All rights reserved.

\section{Corresponding Author:}

Muhammad Win Afgani,

Department of Mathematics Education,

Faculty of Tarbiyah Science and Teacher Training,

Universitas Islam Negeri Raden Fatah Palembang

Jl. Prof. K. H. Zainal Abidin Fikri Km 3,5 Kemuning, Palembang, South Sumatra 30126, Indonesia

Email: muhammadwinafgani_uin@radenfatah.ac.id

\section{How to Cite:}

Afgani, M. W., \& Paradesa, R. (2021). PISA-Like problems using Islamic ethnomathematics approach. Infinity, 10(2), 203-216.

\section{INTRODUCTION}

Minister of Education and Culture Regulation No. 22 of 2016 (MECRI, 2016) emphases that the purpose of learning mathematics at primary and secondary education levels is that students are able to: (1) have mathematical knowledge, (2) use reasoning, (3) solve problems, (4) communicate ideas with symbols, tables, diagrams, or other media to clarify the situation or problem and (5) have an attitude of appreciating the usefulness of mathematics. Mathematical learning objectives are also formulated by the National Council of Teachers of Mathematics, but to realize it is not easy (McKinney \& Frazier, 2008). The results of the Program for International Student Assessment (PISA) and Trends in International Mathematics and Science Study (TIMSS) show that middle-level students in Indonesia still do not have high mathematical abilities. 
Indonesian students have difficulty solving PISA problems because of its problems are very demanding of reasoning and problem-solving ability while they usually solve a mathematics problem that emphasizes mastery of basic mathematics skills. This is in line with the results of Oktaviana et al. (2018), Damayanti and Yunianta (2018), and Aprianti and Kesumawati (2019) study which reported that students' mathematical problem-solving ability is not optimal yet, likewise their mathematical reasoning ability according to Handini et al. (2015), Napitupulu et al. (2016), and Cahyani (2019) study. The abilities are not optimal, according to Afgani (2018) showed that the students' mathematical understanding scheme has a problem. This means that mathematical knowledge schemes that students have learned are not intertwined.

PISA problems also use a global context that is not close to the daily lives of students in Indonesia. As a result, Indonesian students cannot imagine the relevance of the problems to their mathematics understanding, because the use of local cultural contexts, such as Jambi (Charmila et al., 2016; Muslimahayati, 2019), Lampung (Putra et al., 2016), Palembang (Utari, 2017), North Sumatra (Hasanah, 2017), can help students understand the mathematical content contained in the problems. Therefore, to familiarize Indonesian students' interest and accustom to solve mathematical problems in the form of reasoning and problem solving, it is necessary to apply innovation in developing PISA-like mathematical problems with contexts that are close to student life. Meanwhile, Mardhiyanti et al. (2011) reported that PISA-like mathematics problems have positive potential effects on students' mathematical ability.

The involvement of the context in PISA problems is in line with the ethnomathematics approach, but the context under consideration is the culture inherent in the lives of students. With ethnomathematics approach, giving PISA problems to students, besides to develop mathematical reasoning and problem-solving ability or mathematical literacy (Kehi et al., 2019), aims to also introduce the culture that exists around students, so students can better appreciate and preserve the culture. One of the cultures that are around students is Islamic culture, because ethnomathematics in Indonesia relates to it, such as Mosque architecture in Kudus culture (Masamah, 2018), as well as Mosques in Palembang has unique architecture, and also influenced by other cultures. This means that cultural acculturation in mosque buildings shows that Islamic ethnomathematics can be given to a group of multicultural students because it is positioned only as a context of mathematics problems (Kehi et al., 2019). Islamic culture is a consideration to be integrated into the development of the problem because the majority of the population in Palembang is Muslim, so are students in schools who are the subject of this study. Therefore, the additional mission in this research is specific to introduce Islamic culture. Besides that, the presence of nonMuslim students in schools requires researchers to develop mathematical problems with contexts containing Islamic elements without offending them and they do not mind to solve the problems. So, this study aimed to produce PISA-like mathematics problems with the Islamic ethnomathematics approach that were valid and practical based on the considerations for 9th-grade students of junior high school. The Introduction presents the purpose of the studies reported and their relationship to earlier work in the field. It should not be an extensive review of the literature. Use only those references required to provide the most salient background to allow the readers to understand and evaluate the purpose and results of the present study without referring to previous publications on the topic. 


\section{METHOD}

In this study, the method used a development study by Van den Akker (1999). There are five phases that are, self-evaluation, expert review, one to one, small group, and field test. The five phases are called formative evaluation. Before the phases are conducted, the preliminary evaluation conducted firstly. This reference is from Tessmer (1993) and Zulkardi (2002). In a preliminary evaluation, characteristics of the PISA problem, ethnomathematics approach, literature review of Islamic culture in Palembang, and junior high school curriculum in Indonesia were analyzed, and then mathematics problems were developed based on the framework of PISA.

In the first phase of formative evaluation, self-evaluation was conducted to assess the first prototype of PISA-like mathematics problems by the researcher to find the obvious error of words, sentences, and mathematical language. The second phase was an expert review. In this phase, the first prototype was reviewed by experts in mathematics education that are, lecture and teacher. The experts validated the content, construct, and language of the mathematics problems. The instrument used an open and closed questionnaire. For a close questionnaire, the Likert scale was used to collect the data with nine items and four assessments, that are, Strongly Agree (SA), Agree (A), Disagree (D), Strongly Disagree (SD). After that, the open questionnaire was used to verify the reason for their assessment. After the first prototype was revised and become the second prototype, it was tried to students in one to one phase. They were 9th-grade students of junior high school in Palembang. In this phase, the second prototype was tried to see the practicality according to Tessmer (1993) by 3 students with a representative background in mathematical ability that are, low, middle, and high. They were given a chance to solve the problems individually. Like instruments in the expert review phase, one to one phase used a questionnaire with six items and added an interview. The interview was used to identify students' understanding and difficulty in the problems. After the second prototype was revised and become the third prototype, it was tried to small group phase with 3 students. In this phase, practicality about the problems was continued to be observed and used the same instruments like one to one, but the students solve the problems in a group and they were given a chance to discuss it. This phase would produce the fourth prototype. The prototype experimented in a field test with 26 of 9th-grade students of junior high school. In the field test, the instruments used questionnaires and tests to evaluate the practicality. The test was analyzed by three indicators that are, no answer, irrelevance answer, and relevance answer with consecutive scores 0,1 , and 2. For conclusion, the average score was converted by using formula total score divided ideal score, and then multiplied 100. The result was categorized after that.

\section{RESULTS AND DISCUSSION}

\subsection{Preliminary Evaluation Phase}

In this phase, characteristics of the PISA problem, ethnomathematics approach, literature review of Islamic culture in Palembang, and junior high school mathematics curriculum of 2013 in Indonesia were analyzed so that the first prototype with 6 mathematics problems has resulted. It covered one problem with quantity content, two problems with space and shape contents, one problem with change and relationships, one problem with uncertainty content, and one problem with relationship content. The first problem regarding the quantity content related to plane figure concept and quantity of people that occupy an area with certain conditions. The narrative of the problem is as follows (see Figure 1). 
Muslims are required to pray five times a day and night. The Prophet Muhammad SAW strongly recommended that men who were already pubescent do it in the mosque. Estimate the maximum number of adult congregations a mosque that has an area of $200 \mathrm{~m} 2$ of worship can accommodate when praying together? Explain your answer!

Figure 1. The first problem

Based on junior high school mathematics curriculum of 2013, area concept is learned by junior high students in $7^{\text {th }}$ grade, while Islamic ethno that is related to quantity content was praying together in the Mosque building (see Figure 1). Hereinafter, the problem with space and shape content related to the pyramid, and the third problem with the same content related to the circle (see Figure 2).

The typical architectural style at the Great Mosque of Palembang is the roof structure pattern of the main building which is pyramid and consists of three levels. How to sketch the roof of the main mosque, when viewed from above?

The roof of the Great Mosque of Palembang is in the form of a pyramid with a row of golden ornaments in the shape of spearheads like the style of the roofs of Chinese houses, even the minarets of the mosque are in the shape of a pagoda with metal decorations in the shape of a crescent moon and a star at the top. If the crescent moon ornament is sketched from an intersection of two circles with a radius ratio of 0.8 , what is the minimum distance from the center of the two circles to form a crescent moon?

Figure 2. The second problem

Islamic ethno that related to the pyramid was the roof of the great mosque, whereas the intersection of two circles related to the crescent ornament on its roof. Pyramid and circle subject is learned by junior high students in 8th grade, while the intersection is learned in sets subject in $7^{\text {th }}$ grade.

The third problem with change and relationship content related to exponent or power of numbers that are in formula of population growth projection. The narrative of the problem is as follows (see Figure 3).

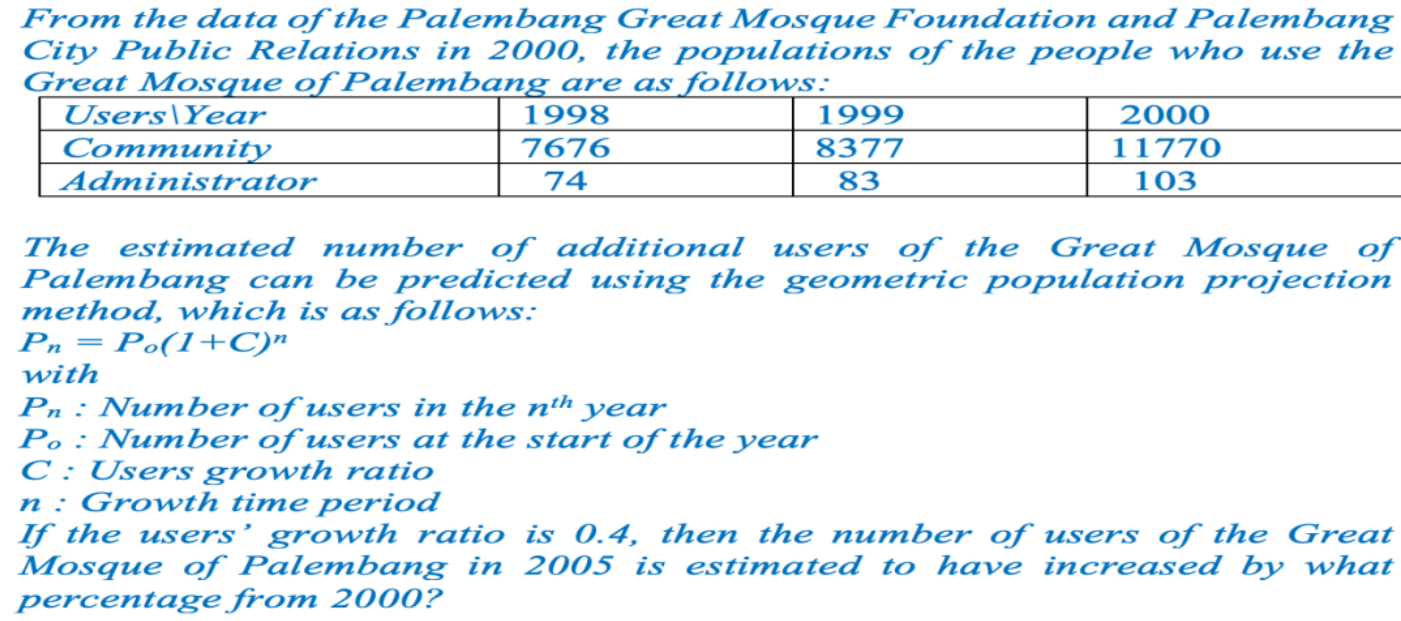

Figure 3. The third problem 
Exponent or power of numbers also related to the degree of algebra form that is learned by junior high school students in $7^{\text {th }}$ grade. Islamic ethno that is involved in the problem was related to cultural pilgrimage activities after doing prayers where they are pilgrims to the Great Mosque which has grown from year to year.

For uncertainty content, the problem that was developed related to data presented in a chart. A line diagram or chart is learned by junior high school students in ${ }^{7 \text { th }}$ grade. The Islamic ethno related to the problem is a culture of preparation wedding that is held by people in Palembang (see Figure 4). In the process of a traditional Palembang wedding, Berasan is the process
of the prospective groom's family determining and agreeing on the amount
of dowry that will be given to the prospective bride according to Islamic
law. If both families agree on a gold dowry amounting to 5 suku ( 1 suku =
6,7 gram) worth almost close to 19.000 .000 IDR, then in what year the event
occurred by observing the gold price chart below? Explain it!

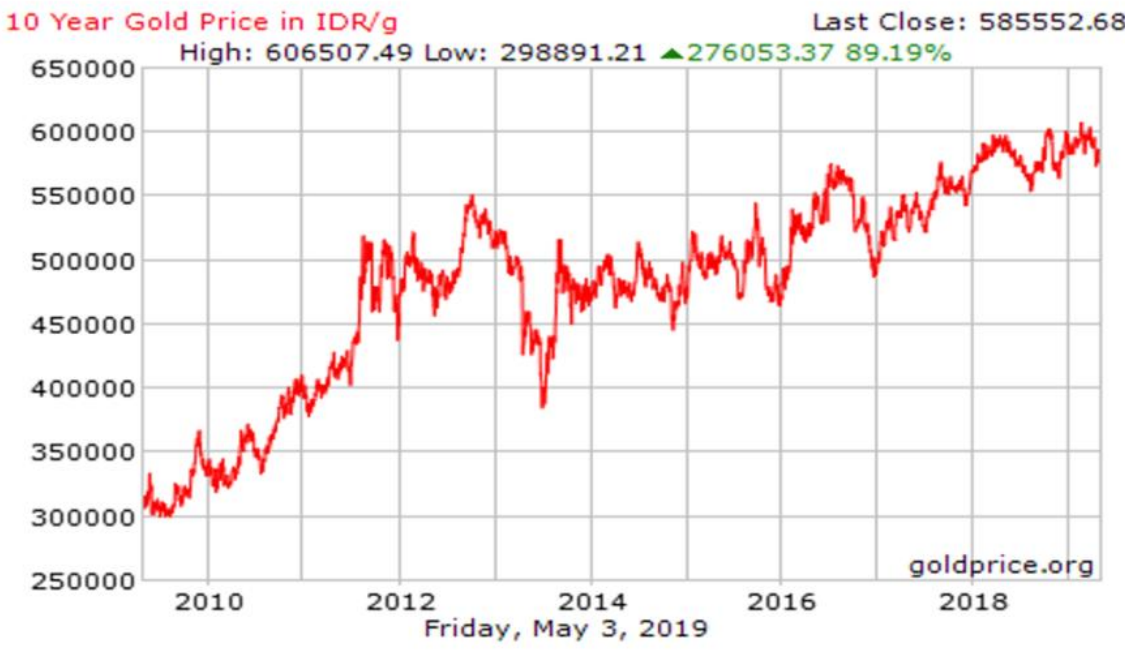

Figure 4. The fourth problem

While the last problem, it covered quantity content and related to the number pattern. Mathematics subject relates to number pattern is learned by junior high school students in 8th grade. Islamic ethno related to the problem is the habits of Muslims in Palembang when performing prayers using prayer beads repeatedly (see Figure 5).

One of the media used for dhikr is tasbih. There is no official source that explains the origin of the tasbih. In Islamic tradition, prayer beads are divided into three groups, each totaling 33 beads. One of the dhikr that is inherent quite strongly in Palembang society is "Lailahaillallahul Malikul Haqqul Mubin Muhammadurr Rasulullah Sadiqul Wa'dul Amin".

If a Muslim recites the dhikr 100 times at a time, s/he will stop at the first or second or third group of 33 tasbih?.

If a Muslim recites dhikr 1000 times at a time, then will s/he stop at the same group of beads as recite 100 times?. Explain your answer!

Figure 5. The fifth problem 
This preliminary phase produced the first prototype of PISA-like problems with the Islamic ethnomathematics approach to be reviewed by the researcher and the experts in the expert review phase.

\subsection{Self-Evaluation Phase}

In this phase, PISA-like mathematics problems that have been designed were evaluated and reviewed independently by the researcher. The result assumed that the first prototype of the PISA-like mathematics problem fulfills content and construct validity based on suitability with the problems characteristic according to PISA framework, ethnomathematics approach, junior high school mathematics curriculum of 2013, and there were not found an obvious error in words, sentences, and mathematical language.

\subsection{Expert Reviews Phase}

In this phase, the first prototype of PISA-like mathematics problems was reviewed by three experts to observe the validity of the problems relate to PISA characteristic framework, ethnomathematics, and compatibility with the curriculum used in junior high school. They are DAK, BAS, and YP. DAK is a lecturer in Padjajaran University, Bandung that has a Doctorate in mathematics education. The second expert, BAS is a mathematics education lecturer at the University of PGRI Semarang that has a Doctorate too. Based on the background of both lectures, the researcher set them as the experts to validate content and construct of the problems via Whatsapp. While YP, she is a teacher of mathematics subject matter at one of the public junior high schools in Palembang that has a master's degree in mathematics education. YP has experience in teaching for 22 years. Because of that background, the researcher also set YP as an expert. They reviewed the content and construct validity of PISA-like mathematics problems are in Table 1.

Table 1. Expert reviews for the first prototype of PISA-Like mathematics problems

\begin{tabular}{|c|c|c|}
\hline No. & Reviewer & Review \\
\hline 1 & DAK & $\begin{array}{l}\text { - For the first problem, the ethno aspect is lacking. If the direction is to } \\
\text { Islamic ethnomathematics, it is not specific enough to mention the } \\
\text { area/region, for example, the scope is narrowed, where the mosque or } \\
\text { prayer location. If the ethno domain in Arab (the center of Islam), then you } \\
\text { should mention the location in Arab, but if in Indonesia, for example, in } \\
\text { Aceh or Demak. If this, it is too general and it leads to thematic problems } \\
\text { or mathematical connections (combining math with Islamic religion } \\
\text { education). It can also be added like this: } \\
\text { The students in pesantren A (the name of the pesantren in the Research area } \\
\text { that is well known, but which is located not in the city, in the suburbs and } \\
\text { still thick customs, as in East Java, for example Gontor), then give a little } \\
\text { narration about the unique habits that are ethnic which was carried out at } \\
\text { the pesantren, for example ceremonies making red and white porridge } \\
\text { when celebrating the birthday of the prophet Muhammad (if in East Java, } \\
\text { there are habits like that). The problem can be developed again, which is } \\
\text { dug up from the culture that is usually done by the students (not only about } \\
\text { the size of the mosque, can be to the maximum number of Al-Quran that } \\
\text { must be provided if there are so many students who enter per semester), } \\
\text { which represents "culture" here is the habitual activity of the students who } \\
\text { "fuse" with the local culture (the community around the pesantren). }\end{array}$ \\
\hline
\end{tabular}




\begin{tabular}{|c|c|c|}
\hline No. & Reviewer & Review \\
\hline & & $\begin{array}{l}\text { - For the second problem, the ethno isn't deep enough. Just because of the } \\
\text { word "typical architecture of the great mosque of Palembang", so it's still } \\
\text { lacking. The architecture of the Great Mosque of Palembang is influenced } \\
\text { by what? } \\
\text { - For the third problem, is it Palembang ethno or China? the ethno is obscure. } \\
\text { - For the fourth problem, this is more contextual. } \\
\text { - For the fifth problem, this seems appropriate, because Palembang ethno } \\
\text { exists and Islam also exists. "Suku" is the name of a unit of weight typical } \\
\text { of Palembang?. Ethnomath in Palembang Interesting too. } \\
\text { - For the sixth problem, if this is too Islamic and the ethno is not compatible } \\
\text { yet. This is more of a historical Islamic contextual or this problem can be } \\
\text { completed with specific tribal names. Ethno must bring up "cultural } \\
\text { uniqueness" and the definition of CULTURE here is different from } \\
\text { ROUTINITY. }\end{array}$ \\
\hline 2 & BAS & $\begin{array}{l}\text { The problem of relationship content (no. 6) and quantity content (no. 1) are } \\
\text { okay, the problem of uncertainty content is okay (no. 5), the problem of } \\
\text { change and relationship (no. 4) is less related to Islam and can still be used } \\
\text { in context and need to state the validity of the formula, it must be explored } \\
\text { again. Problem no. } 2 \text { and } 3 \text { need to add images. }\end{array}$ \\
\hline 3 & YP & $\begin{array}{l}\text { The problems are already quite good and under the local cultural content, but } \\
\text { some writings are not under the rules of the Indonesian language, for } \\
\text { example, the name of the place that still uses lowercase letters, as in problem } \\
\text { no. } 6 \text {, Palembang is written with palembang. Overall, the problems are good. }\end{array}$ \\
\hline
\end{tabular}

From their review, the first prototype was revised and become the second prototype. Hereinafter, the three experts assessed again the validity of the problems that had been developed through a questionnaire. The results of the data from the questionnaire can be seen in Table 2.

Table 2. The validity of the second prototype according to experts review

\begin{tabular}{cccccc}
\hline \multirow{2}{*}{ No } & \multirow{2}{*}{ Reviewer } & \multicolumn{4}{c}{ Rating } \\
\cline { 3 - 6 } & & SA & A & D & SD \\
\hline 1 & DAK & $22.22 \%$ & $77.78 \%$ & $0.00 \%$ & $0.00 \%$ \\
2 & BAS & $0.00 \%$ & $100 \%$ & $0.00 \%$ & $0.00 \%$ \\
3 & YP & $33.33 \%$ & $55.56 \%$ & $11.11 \%$ & $0.00 \%$ \\
\hline & Average & $18.52 \%$ & $77.78 \%$ & $3.70 \%$ & $0.00 \%$ \\
\hline
\end{tabular}

From the validity result in Table 2, the second prototype of problems was valid in content and construct which about $77.78 \%$ of three experts assessed agree that PISA-like mathematics problems that were developed fulfill valid criteria. In the next phase, one to one phase, the second prototype of problems experimented with three students with different cognitive ability that is low, middle, and high. 


\subsection{One to One Phase}

In this phase, the researchers tested the second prototype problem to see its practicality to three students of 9th grade with three abilities, namely high, medium, and low. The researcher assigned them to solve the problems individually. The results of interviews with teachers obtained information that students who have the mathematical high ability are $\mathrm{NB}$, the medium ability is MR, and low ability is AD. The assessment of the three students in this phase regarding the practicality of the problems can be seen in Table 3.

Table 3. The practicality of the second prototype on one to one phase

\begin{tabular}{cccccc}
\hline \multirow{2}{*}{ No } & \multirow{2}{*}{ Student } & \multicolumn{5}{c}{ Rating } \\
\cline { 3 - 6 } & & SA & A & D & SD \\
\hline 1 & NB & $16.67 \%$ & $83.33 \%$ & $0.00 \%$ & $0.00 \%$ \\
2 & MR & $0.00 \%$ & $66.67 \%$ & $33.33 \%$ & $0.00 \%$ \\
3 & AD & $0.00 \%$ & $83.33 \%$ & $16.67 \%$ & $0.00 \%$ \\
\hline \multicolumn{2}{r}{ Average } & $5.56 \%$ & $77.78 \%$ & $16.67 \%$ & $0.00 \%$ \\
\hline
\end{tabular}

From the results of the questionnaire (see Table 3), about $77.78 \%$ of three students considered agree that the second prototype problems met the practicality criteria. Also, the three students gave comments on the problems they solved. Their comments are presented in Table 4.

Table 4. Student comments on the second prototype problem

\begin{tabular}{|c|c|c|}
\hline No & Student & Comments \\
\hline 1 & NB & $\begin{array}{l}\text { - The problems are too many explanations, so they must be } \\
\text { understood more deeply. } \\
\text { - The contents of several problems have not been studied. } \\
\text { - The problems have not led to the imagination. }\end{array}$ \\
\hline 2 & MR & $\begin{array}{l}\text { - The problem that is difficult for me is part of the circle ratio and the } \\
\text { increasing population of mosque users. } \\
\text { - The contents of the problems are less interesting because there are } \\
\text { too many narratives, preferably lots of pictures, and the sentences } \\
\text { are concise. } \\
\text { - The contents of the problems are quite confusing because there are } \\
\text { problems related to the content in } 8^{\text {th }} \text { grade, so it has been forgotten, } \\
\text { it should be following the current material only. }\end{array}$ \\
\hline 3 & $\mathrm{AD}$ & $\begin{array}{l}\text { - The contents of the problem are not interesting to solve because I } \\
\text { forgot how to solve them. } \\
\text { - The meaning of the problems is not confusing, but the way to solve } \\
\text { them is confusing. }\end{array}$ \\
\hline
\end{tabular}

From the comments of the three students, MR had difficulty understanding an intersection of two circles with a radius ratio of 0,8 . He sketched the intersection as one circle sliced into two halves. To guide his understanding by interview, researcher gave an analogy of intersection of two sets. When he was asked about an intersection of two sets, he knowed it and could give an example. His explanation was sketched on Figure 6. 


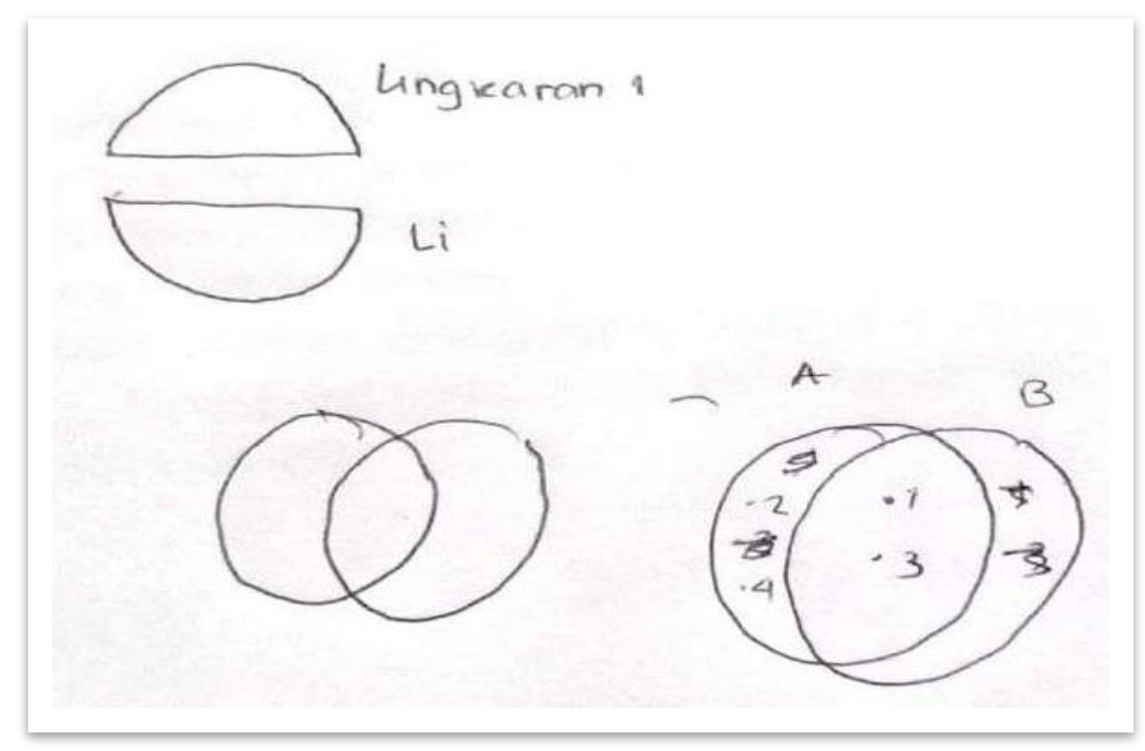

Figure 6. Student sketches of an intersection of two circles

Figure 6 show that MR could sketch of an intersection of two sets, that are, A and B, but could not relate yet the concept of an intersection of two sets with two circle, so he could not solve the problem. This mean that the problem need to be revised, because his misconception about an intersection of two circles. He suggested that the problems should add a figure and reduce the narrative. So, not only MRs' comment but also NB and AD, the second prototype problem was revised to become the third prototype. The next step was testing the third prototype problem to the small group phase on three different students from before.

\subsection{Small Group Phase}

In the small group phase, the researchers tested the third prototype problem to see its practicality to three students of 9th grade. To get it, the same as in the one to one phase, the researcher asked the teacher for help. The teacher determined ADA, NDP, and AT. The student who has a high mathematical ability was ADA, the medium ability was NDP, and the low ability was AT. At this phase, the three students were allowed to discuss how to solve each given problem. The assessment of the three students in this phase regarding the practicality of the problems can be seen in Table 5 .

Table 5. The practicality of the third prototype on small group phase

\begin{tabular}{cccccc}
\hline \multirow{2}{*}{ No } & \multirow{2}{*}{ Student } & \multicolumn{4}{c}{ Rating } \\
\cline { 3 - 6 } & & SA & A & D & SD \\
\hline 1 & ADA & $16.67 \%$ & $83.33 \%$ & $0.00 \%$ & $0.00 \%$ \\
2 & NDP & $66.67 \%$ & $33.33 \%$ & $0.00 \%$ & $0.00 \%$ \\
3 & AT & $100 \%$ & $0.00 \%$ & $0.00 \%$ & $0.00 \%$ \\
\hline \multicolumn{2}{r}{ Average } & $61.11 \%$ & $38.89 \%$ & $0.00 \%$ & $0.00 \%$ \\
\hline
\end{tabular}


From the results of the questionnaire (see Table 5), the third prototype problems was practical because about $61.11 \%$ of the three students stated strongly agree. Also, the three students gave comments on the problems they solved (see Table 6).

Table 6. Student comments on the third prototype problem

\begin{tabular}{ccl}
\hline No & Student & \multicolumn{1}{c}{ Comments } \\
\hline 1 & ADA & $\begin{array}{l}\text { The problems presented are under the material being studied, but } \\
\text { indeed the material is little developed, so the level of the process is } \\
\text { more difficult than usual. }\end{array}$ \\
2 & NDP & $\begin{array}{l}\text { The problems given are understandable. The questions discussed are } \\
\text { better accompanied by pictures so that the contents in the problems are } \\
\text { interesting to discuss and include problems about pray with prayer } \\
\text { beads. } \\
\text { Great, the problem is very easy to understand. }\end{array}$ \\
& AT &
\end{tabular}

From the comments of the three students and the results of observations as they tried to solve them, the third prototype question was revised to become the fourth prototype. The prototype also revised due to they could not solve all the problems, but one of interesting answers of them was the answer when they solved a problem about a Muslim recites dhikr 1000 times at a time. In solving it, ADA more active than NDP and AT. Discussion occurred between ADA and NDP, while AT just watched. In her explanation, ADA used a different strategy from NB's answer in the one to one phase. If NB divided $1000 \mathrm{dhikr}$ with 33 beads, then she had passed 30 groups of tasbih. Since the tasbih was divided into 3 groups, he had done one complete cycle of 10 times and had been doing tasbih 990 times. Meanwhile, the next 10 dhikr occurred in the first group. While ADA's method, she divided or compared 1000 to 100 times of dhikr. Because the result was 10, according to ADA, the 10 beads were still in the first group. The ADA answer could be interpreted as AD's answer in the one to one phase, which is like a person who recited 100 times during 10 times where 99 beads had passed one prayer beads round and the next 1 beads returns to the first group of beads. From the two answer strategies, this showed that the problem has made students creative in finding ways to solve problems, without having to use standard mathematical formulas. According Afgani and Paradesa (2019), when student found strategy to solve mathematical problem by him/herself, that mean that s/he had constructed and improved her/his mathematical knowledge. The next step was testing the fourth prototype problems to the field test phase on several students in one class.

\subsection{Field Test Phase}

At this phase, the researcher tested six problems of the fourth prototype to 26 students' junior high school of 9th grade. The problems were given simultaneously to students with 80 minutes. Before the problems were given, the researcher identified the religion of all students. This was done to consider the existence of non-Muslim students if she feels objected to being involved in learning. From the results of identification, there was one non-Muslim student. When she was asked about the objections, she answered wanting to stay involved and did not mind. Next, they were assigned to solve the problems individually. After they have worked with the time limit that has been determined, a questionnaire regarding the practicality of the problems was given to students. The following 
is an evaluation of the practicality of the fourth prototype problems according to the students which can be seen in Figure 7.

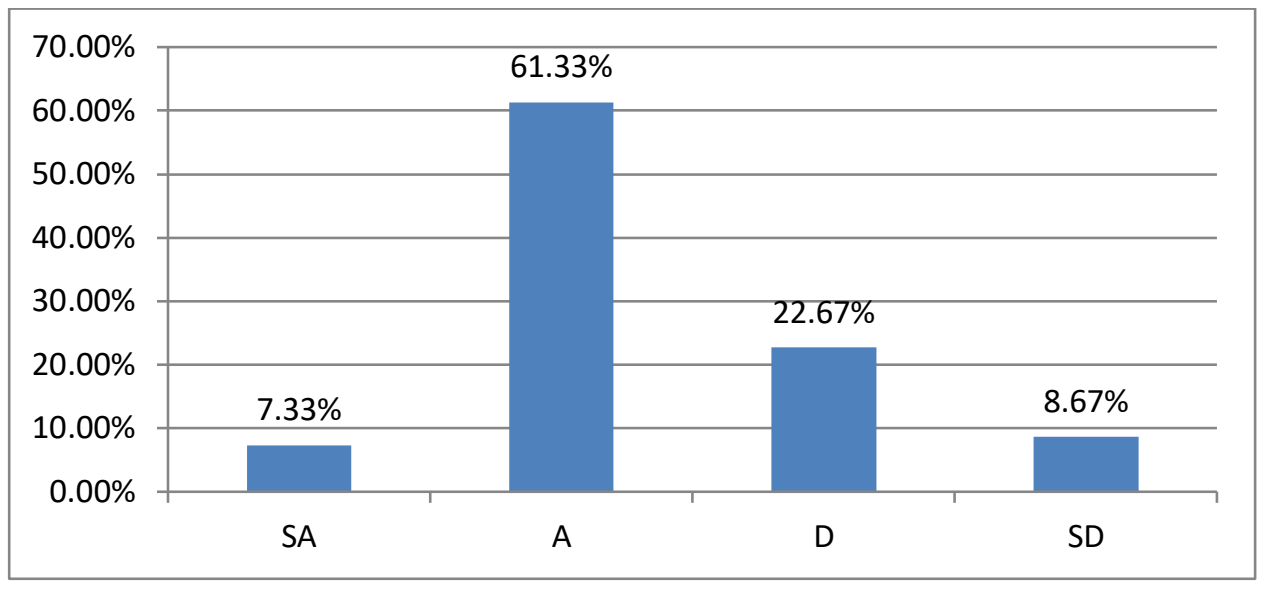

Figure 7. The practicality of the fourth prototype on field test phase

Figure 7 show that $61.33 \%$ of 26 students agreed that the problems developed had met the practicality criteria. Also, they provided comments on the assessment given to the problems developed. Some of their comments were as follows:

a. The problem can be solved but it takes a very long time.

b. The material provided is easy to understand and is related to mathematical material that has been studied.

c. The problems provided are interesting by containing interesting stories as well.

d. The problems given are easy, medium, some are difficult, and are related to everyday math material in grade 9.

e. The material in the problem should be discussed first in front of the class so that I can smoothly solve the problem. The problems given are rather complicated and it seems that I rarely get problems like that.

f. All the problems given are interesting to solve but some are difficult.

g. This problem is more interesting to discuss than the usual problem, but without explanation this problem is complicated, so I am lazy to do it.

From some of the students' comments, the problems that had been developed meet three difficulty levels, namely easy, medium, and high. This means students understood the problems given when they are easy to find a solution and students did not understand the problems when they are difficult to find a solution. They also complained about too much narration. This showed that narratives that are too long can eliminate the attraction to find mathematical solutions. Also, they realized that it is difficult to solve the problems because they were rarely trained in PISA questions, but they also found the problems given interesting, because they contained contexts related to the Islamic culture around them. This finding is following the results of research by Nizar et al. (2018) who reported that the integration of daily contexts that are close to students' lives into mathematical problems can make students actively discuss and assist them in solving them. Their interest was also expressed from their curiosity about the answers to the problems given where they hoped that the problems would be discussed together in mathematics learning.

The results of research at this phase, the conclusions that could be drawn are problems that have been developed until the fourth prototype has not met the optimal practicality criteria because $31.34 \%$ of students gave negative responses. This finding was 
not much different from the results of Susanti and Suparman (2018) who reported that $27.5 \%$ of students gave negative responses to the problems in the worksheet related to ethnomathematics. This means that PISA-like problems using the Islamic ethnomathematics approach need to be further developed. Student negative responses are still quite large showed the schema of students' understanding of mathematical problems contained in the problem also had problems. This is evident from the results of the test data which showed the average score of students is 38.46 with the standard deviation is 13.14 . On a scale of 0 100 , the score is included in the low category. This result was consistent with Hasanah's research results (2017). She reported that the mathematical abilities of junior high school students in North Sumatra who were the subject of her research in solving problems of the PISA model with the local cultural context were still in the low category. This means students who understand the problem, may not be able to find a solution, because in terms of problem-solving strategies according to Polya, understanding the problem is only the first step of the four steps to solve the problem to arrive at a re-examination of the strategy taken.

\section{CONCLUSION}

Based on the result of this study, we concluded that PISA-like mathematics problems that had been developed using Islamic ethnomathematics approach were valid and practical for 9th grade students of junior high school, but still needs to be developed continually, because about $77.78 \%$ of three experts assessed agree that the problems that were developed fulfill valid criteria. In terms of practicality criteria, about $77.78 \%$ of three students on one to one phase considered agree, about $61.11 \%$ of the three students on small group phase stated strongly agree, and about $61.33 \%$ of 26 students agreed that the problems met the criteria. This result is supported by the average test result that was classified as a low category, which is 38.46 of 100 . From this conclusion, we recommend to develop it not only in the form of problems directly but also in the form of worksheets. This will guide and get them used to solve PISA mathematics problems.

\section{ACKNOWLEDGMENTS}

The author would like to thank the Institutions of Research and Community Service of Raden Fatah State Islamic University which have given research funding, so that authors could finish it without any significant obstacles. Last but not least, authors render thanks and give respect very grateful to all other individuals who have supported authors to writing this paper.

\section{REFERENCES}

Afgani, M. W., \& Paradesa, R. (2019). Perbedaan skala pada sumbu koordinat kartesius: apa dampaknya dalam pembelajaran integral tentu?. Jurnal Pendidikan Matematika, 13(2), 121-130. https://doi.org/10.22342/jpm.13.2.6819.121-130

Afgani, M. W. (2018). Peningkatan kemampuan pemahaman matematis dan konsep diri mahasiswa calon guru matematika melalui penerapan siklus pembelajaran aktivitasdiskusi-latihan berdasarkan teori APOS. Doctoral dissertation. Bandung: Universitas Pendidikan Indonesia.

Aprianti., \& Kesumawati, N. (2019). Pengaruh Model Auditory Intellectual Repetition Terhadap Kemampuan Pemecahan Masalah Ditinjau dari Disposisi Matematis di 
SMP. Jurnal Pendidikan Matematika RAFA, 5(1), 10-21. https://doi.org/10.19109/jpmrafa.v5i1.2729

Cahyani, P. A. (2019). Kemampuan penalaran matematis peserta didik melalui model pembelajaran reciprocal teaching dengan berbantuan alat peraga "kartu pintar" pada materi prisma dan limas kelas VIII SMP Negeri 1 Pandaan tahun ajaran 2017/2018. Jurnal Pendidikan Matematika (JPM), 5(1), 28-36. https://doi.org/10.33474/jpm.v5i1.2627

Charmila, N., Zulkardi, Z., \& Darmawijoyo, D. (2016). Pengembangan soal matematika model PISA menggunakan konteks jambi. Jurnal Penelitian dan Evaluasi Pendidikan, 20(2), 198-207. https://doi.org/10.21831/pep.v20i2.7444

Damayanti, E. R., \& Yunianta, T. N. H. (2018). The profile of junior high school students' problem solving in answering the content pisa test of uncertainty and data based on ideal problem solving. MaPan: Jurnal Matematika dan Pembelajaran, 6(2), 250264. https://doi.org/10.24252/mapan.2018v6n2a10

Handini, L., Amilda, A., \& Arifin, S. (2015). Pengaruh pendekatan open ended dalam pembelajaran matematika terhadap kemampuan penalaran siswa kelas VII di SMP PTI Palembang. Jurnal Pendidikan Matematika RAFA, 1(2), 204-223.

Hasanah, H. (2017). Efektivitas soal-soal matematika tipe PISA menggunakan konteks budaya Sumatera Utara untuk mendeskripsikan kemampuan penalaran dan komunikasi matematis siswa SMP Kota Medan. AXIOM: Jurnal Pendidikan dan Matematika, 6(1).

Kehi, Y. J., Mastur, Z., \& Waluya, St. B. (2019). Kontribusi etnomatematika sebagai masalah kontekstual dalam mengembangkan literasi matematika. PRISMA, 2, 190196.

Mardhiyanti, D., Putri, R. I. I., \& Kesumawati, N. (2011). Pengembangan soal matematika model PISA untuk mengukur kemampuan komunikasi matematis siswa sekolah dasar. Jurnal Pendidikan Matematika, 5(1). https://doi.org/10.22342/jpm.5.1.334.

Masamah, U. (2018). Pengembangan pembelajaran matematika dengan pendekatan etnomatematika berbasis budaya lokal Kudus. Jurnal Pendidikan Matematika (Kudus), 1(2), 123-144. https://doi.org/10.21043/jpm.v1i2.4882

McKinney, S., \& Frazier, W. (2008). Embracing the principles and standards for school mathematics: An inquiry into the pedagogical and instructional practices of mathematics teachers in high-poverty middle schools. The Clearing House: A Journal of Educational Strategies, Issues and Ideas,81(5), 201-210. https://doi.org/10.3200/TCHS.81.5.201-210

Ministry of Education and Culture of the Republic Indonesia [MECRI]. (2016). Peraturan menteri pendidikan dan kebudayaan republik Indonesia nomor 22 tahun 2016 tentang standar proses pendidikan dasar dan menengah. Jakarta: Kementerian Pendidikan dan Kebudayaan Republik Indonesia.

Muslimahayati, M. (2019). Kemampuan komunikasi matematis siswa dengan pendekatan pembelajaran matematika realistik bernuansa etnomatematika (PMRE). Jurnal Pendidikan Matematika RAFA, 5(1), 22-40. https://doi.org/10.19109/jpmrafa.v5i1.3773 
Napitupulu, E. E., Suryadi, D., \& Kusumah, Y. S. (2016). Cultivating upper secondary students' mathematical reasoning-ability and attitude towards mathematics through problem-based learning. Journal on Mathematics Education, 7(2), 117-128. https://doi.org/10.22342/jme.7.2.3542.117-128

Nizar, H., Putri, R. I. I., \& Zulkardi. (2018). PISA-like mathematics problem with karate context in Asian Games. Journal of Physics: Conference Series, 1088(1), 012063. https://doi.org/10.1088/1742-6596/1088/1/012063

Oktaviana, D. V., Syafrimen, S., \& Putra, R. W. Y. (2018). Analisis kemampuan pemecahan masalah matematis siswa kelas IX MTs dalam menyelesaikan soal model PISA pada konten perubahan dan hubungan. Jurnal Edukasi dan Sains Matematika (JESMAT), 4(1), 47-56. https://doi.org/10.25134/jes-mat.v4i1.909

Putra, Y. Y., Zulkardi, Z., \& Hartono, Y. (2016). Pengembangan soal matematika model PISA level 4, 5, 6 menggunakan konteks lampung. Kreano, Jurnal Matematika Kreatif-Inovatif, 7(1), 10-16. https://doi.org/10.15294/kreano.v7i1.4832

Susanti, D., \& Suparman, S. (2018). Analisis kebutuhan lembar kerja siswa etnomatematika batik geometri transformasi. Prosiding Seminar Nasional Pendidikan Matematika Etnomatnesia, 1, 209-213.

Tessmer, M. (1993). Planning and conducting formative evaluations: Improving the quality of education and training. London: Psychology Press.

Utari, R. S. (2017). Desain pembelajaran materi perbandingan menggunakan konteks resep empek-empek untuk medukung kemampuan bernalar siswa SMP. Jurnal Pendidikan Matematika RAFA, 3(1), 103-121. https://doi.org/10.19109/jpmrafa.v3i1.1444

Van den Akker, J. (1999). Principles and methods of development research. In Design approaches and tools in education and training (pp. 1-14). Dordrecht: Springer. https://doi.org/10.1007/978-94-011-4255-7_1

Zulkardi, Z. (2002). Developing a learning environment on realistic mathematics education for Indonesian student teachers. Doctoral dissertation. Enschede: University of Twente. 